\title{
IV. Memoir on tubes rendered harmonious by hydrogen gas. Read before the Society of Physics and Natural History of Geneva
}

\section{G. Delarive}

To cite this article: G. Delarive (1802) IV. Memoir on tubes rendered harmonious by hydrogen gas. Read before the Society of Physics and Natural History of Geneva, Philosophical Magazine Series 1, 14:53, 24-31, DOI: 10.1080/14786440208676155

To link to this article: http://dx.doi.org/10.1080/14786440208676155

曲 Published online: 18 May 2009.

Submit your article to this journal $\pi$

Џll Article views: 2

Q View related articles $\sqsubset$ 


\section{Tubes rendered barmonious by fiydrogen Gas.}

Confequently, by fuppreffing from the colours of hard porcelain the carmine of gold, which is not indifpenfably neceffary, we thall have a feries of colours which do not change, and which will be abfolutely fimilar to thofe prefented to the Inftitute in the year 6 .

IV. Memoir on Tubes rendered barmonious by Hydrogen Gas. Read before the Society of Phyfics and Natural Higlory of Generva, by G. Dela rive, Ex-Prefident of the Royal Society of Edinburgh, and Member of the Medical Colleges of London and Geneva*.

$I$

a former fitting, our learned colleague profeffor PiEtet communicated to the fociety a feries of refearches on tubes rendered harmonious by means of hydrogen gas, and explained the different mufical phænomena to which thefe tubes give birth. He pointed out the influence of the length of the tube; of its breadth, and of the place where the gas is burnt; and explained the nature of the founds produced. In regard to the caufe of the found, he offered only conjectures: as his labour was not directed to that object, it is under this point of view that I have refumed it.

Profeffor Brugnatelli, in my opinion, is the firtt perfon who publifhed the experiment; which I thall endeavour to explain. It had been invented by a German : I fhall here give a view of the pincipal circumftances attending it.

If a current of inflamed hydrogen gas be introduced into a tube the fubitance of which is elaftic and fonorous, fuch as glafs, metal, dry wood, \&c., this tube, after the interval of fome feconds, will enit a harmonic found: if it be open at both extremities, the found will be ftrong and full. The experiment may, however, fucceed with a tube clofed hermetically at one end, provided its diameter be fo large as to admit of a circulation of the atmofpheric air in fufficient quantity to maintain the combuftion of the gas. The conditions ef fentially neceffary for this purpofe are: Ift, That the fubftance of the tube be elaftic, proper for producing an echo; that is to fay, for reflesting the undulations which proceed from the fonorous point: a tube of paper or pafteboard will emit no found. $2 d$, The flame muft be produced by a current of hydrogen gas. An inflamed jet of the vapour of fpirit of wine or ether, a lighted taper, \&c. are incapable of making the tube emit any found.

* From the jouminal de Pbyfigue, Fruetidor, an. 10. 
Let us now examine what takes place in this experiment. There muft be a certain point, which may be called the fonorous point; it is at this point that the vibrations which communicate to the arr an undulatory motion are produced. This point is the place of combuftion; for by changing the pofition of that place the founds may be varied, as M. Pictet proved by a feries of experiments. This gentleman obferved alfo in that point, by means of the fmoke with which he filled the tube, a continual fucceffion of vibrations. Thete vibrations give birth to undulations, which are propagated with a known and determined velocity, and, ftriking the fides of the tube, are reflected with the fame velocity as that with which they reached them. When the diftance of the fides of the tube is fuch that the reflections backwards and forwards are ifochronous with the vibrations natural to the fonorous caufe, the found increafes in intenfity, and becomes mufically appreciable. It appears alfo that the reflected undulations re-act on the primitive vibrations produced in the place of combution, and render them harmonically regular with them; for a certain fpace of time is almoft always neceffary before the inftrument bas acquired a regular and full found: the tone of the tube will be higher or lower according to the greater or lefs number of undulations which take place in a given time.

There is another effential fact to be obferved in the experiment which we here examine: the temperature of the column of air is not the fame throughout its whole length. At the fonorous point, that is to fay, the place of combution, the temperature is exceedingly high; it is fuch, that the extremity of the aperture of the glafs through which the hydrogen gas iffues is conftantly in a ftate of incandefcence : if an inflamed jet of the vapour of fpirit of wine or ether be fubftituted for a current of hydrogen gas, the heat is vifibly weaker. According to fome experiments it appears probable alfo that the temperature of the chamber where the experiment is made, and the purity of the air in the chamber, may have fome influence on the refult.

The object of my refearches was to difcover the caufe of thefe phænomena, and how, and by what means, thefe fonorous vibrations are produced. During the combuftion of hydrogen gas, it is well known that there is a production of water, and this water appears under the form of vapours. The place of the combultion being at a high temperature, thefe vapours muft acquire a large volume; but, coming immediately into contact with air lefs heated, their volume muft be rapidly diminifhed. A vacuum therefore mult be formed, 
into which the air rumes to be repelled by the new vapours, that contract in their turn. Is it from this alternate motion, produced by the great expanfion and fubfequent contraction of the vapours, that the fonorous vibrations refult *?

Such were the conjectures which might be formed on the probable caufe of this phænomenon, when I accidentally met with a fact which appeared to me to give them fome weight.

I had a thermometer tube about a line in diameter, at the extremity of which a fmall bulb was blown. In this bulb was a drop of water, which I wifhed to expel: for this purpofe I expofed the bulb feveral times to the flame of a fpiritof-wine lamp. I was agreeably furprifed to hear the tube emit a harmonious found.

To repeat this experiment with fuccefs, the tube employed muft be from I to 2 or 3 lines in diameter: its length may be about from 3 to 4 or 5 inches : it muft have blown at one of its extremities a bulb the diameter of which is about triple that of the tube. It is not neceffary that it thould be regular. It even appears that, if it were a little flatted, the found emitted would be higher. Into this bulb introduce a little quantity of water or mercury, and then expofe it to a ftrong heat : that of a common fpirit-of-wine lamp will, in general, be fufficient; but the flame muft be large and ftrong when the operation is performed with a large tube. After the bulb has been expofed for fome moments to the heat, it will emit a found. Tubes of a large diameter produce a found lower

* It appears to me probable that the found produced by the air which ruthes into the vacuum is more intenfe than that which refults from an expanfive force. The dreadful noife occafioned by the detonation of bubbles of hydrogen gas and oxygen is well known, and yet the lighteft objects which furround the velfel are not even agitated by it; whence we may conclude that this phanomenon is produced by the fudden vacuum refulting from the deftruction of the gas. The detonation of an inflammable gas pifol is much ftronger than that of the air-gun, though the effect is lefs confiderable; probably becaufe in the piftol a vacuum fucceeds the firft expanfive force. Every body is acquainted with that children's plaything called the humming top. It confits of a hollow fphere with an sperture at the circumference, which being made to turn rapidly on its axis produces a very ftrong humming noife. What is the caufe of this noife? The fame, in my opinion, as that above mentioned: the centrifugal force expels the air from the fphere through its aperture; a kind of xacuum is formed in it, the exterior air continually tends to enter it, and is immediately repelled, and hence a feries of fonorous ofcillations. - The AUTHOR,

The effect here fpoken of feems rather to arife from the velocity with which the edge or lip of the orifice meets the dir ; for the fame found may be produced by directing a ftream of air againt the lip when the top is fationary.-EDIT. 
than others. The fize of the bulb appears to me alfo to contribute towards the fame effect. The found will be perma. nent for fome moments; it will then gradually decreafe, and at length will entirely cèafe. By fuffering the apparatus to cool, and taking care to make the liquid condenfed along the fides of the tube to defcend into the bulb, the experiment may be repeated as often as may be thought proper.

Such is the experiment by means of which, in my opinion, the phænomenon of the harmonious tubes may be explained in a fatisfactory manner. Let us now examine what takes place in tubes with a bulb, and what are the effential conditions neceffary to nuake them emir a found, and let us endeavour to difcover the caufe of this found. We thall then compare them with the tubes employed with hydrogen gas, and thall examine in what thefe two inftruments refemble each other in the effects they produce, the differences they exhibit under the fame relations, and the caufes of thefe ditferences.

The effential conditions neceffary to make tubes with a bulb refound are: Ift, That the veffel has a bulb: I was never able to excite fonorous vibrations in a tube fimply clofed at one of its extremities. $2 \mathrm{~d}$, This bulb muft contain an evaporable liquid: water fucceeds very well; but it is attended with the difadvantage of forming in the tube, when it paffes from the ftate of vapour to the liquid ftate, a finall drop which often obftucts it entirely, and, fometimes, falling on the heated part of the glafs, occafions a rupture. Mercury is not attended with the fame defect : I was never able to produce founds with ether, fpirit of wine, or concentrated fulphuric acid. The quantity of liquid contained in the bulb is not a matter of indifference; it muft be as fmall as poffible: if there be too much, the tube becomes filled with vapours, which completely expel the air from it, and, heating it every where in an uniform manner, it no longer emits any found. The third effential condition is the application of $a$ ftrong heat to the bulb while the reft of the tube remains cold; for, if there be not a very ftriking difference of temperature between the bulb and the tube, there will be no fonorous effect. In the laft place, the prefence of atmofpheric air is indifpenfably neceffary: if it be entirely expelled, no effect can be produced. In all the periods of the experiment it will be found that the vapour fills only a certain portion of the inftrument, and that it always contains air. I made feveral trials to determine cxactly the fpace occupied by the vapour at the moment when the found is heard; and I have found that, in fmall tubes at leaft, this fpace is fomewhat lefs 
than the volume of the bulb. To determine it, I fhut with my finger the orifice of the tube: at the moment when it began to found, I inmerfed the orifice in mercury, removed my finger, and left the apparatus to cool. The vapour became condenfed; and I could judge, by the quantity of mercury which the preffure of the atmofpheric air made to afcend in the tube, the fpace which the vapour had occupied.

Such are the four conditions effentially neceffary for obtaining founds: a bulb at the extremity of the tube; the prefence of a very fmall quantity of water or mercury in the bulb; the application of a ftrong heat to the bulb while the reft of the tube remains cold; and, in the ldft place, the fimultaneous prefence in the apparatus of vapour and atmofpheric air. It is not neceflary to add, that the orifice of the tube mult always be open. Let us now examine what may be the caufe of the found. I wilhed firft to afcertain whether any chemical decompofition of the liquid employed took place. For this purpofe $I$ took a tube of fuch a length that the liquid might be entirely condenfed in it. I weighed it carefully before I made the experiment: I then made it emit founds, and found, after producing this effect feveral times, that its weight had neither increaled nor decrealed; whence I concluded that caloric produces no chemical effect on the liquid, and that the latter merely undergoes fucceflive evaporation and condenfation. Is it to this evaporation, then, of the liquid, and its condenfation, that the founds ought to be afcribed? At firft I believed that this queftion might be anfwered in the affirmative; but the following confiderations made me change my opinion: I firft obferved that there might be a fucceffive evaporation and condenfation, without the tube emitting any found, on applying to the bulb a fuffcient heat, but lefs intenfe than that neceffary for making the tube found. Secondly, in making the experiment with a drop of water, I conftantly found that the moment when the apparatus began to enter into action was that when the whole of the water was evaporated, and, confequently, when the heat acted on the vapour: if a fingle atom of liquid remained in the bulb, the tube was mute. From this fact I conclude that the found is produced by the action of the caloric on the vapour, and the reaction of the latter on the atmofpheric air. The following is the manner in which I conceive that this phænomenon takes place: The vapour contained in the bulb reccives, by an addition of caloric conveyed to it from every part in a large quantity, an increafe of volume and of elafticity; it procecds with force from the bulb to the tube, and expels the air contained in it; but this air and the fides 
of the tube take from it, at the moment of contact, a portion of the caloric, its volume decreafes, at the fame inftant $\boldsymbol{a}$ racum takes place, and the air refumes its primitive fpace. A new addition of caloric reftores to the vapour its whole elafticity, a part of which it foon lofes in the fame manner. This is a confequence of the ofcillations of that nature which give to the air an undulatory movement. The undulations refiected by the fides of the tube become fonorous and appreciable when they are ifochronous with the ofellations prod'nced by the caufe I have indicated. From fome tubes it is impoffible to produce any found: in thefe I am of opinion that the reflected undulations cannot harmonize with the primitive ofcillations, and that the one deftroy the other. In tubes with bulbs, the found, after a certain time, becomes weaker, and at length ceafes. This may be explained by the propagation of heat along the fides. When the bulb is very warm, and the tube cold, the vapour which rifes from the bulb fuddenly lofes a part of its volume, and the ofcillationg thus produced are ftrong and frequent; but when the tube has acquired a certain degree of heat, the vapour gradually decreafes in volume by paffing from a very hot temperature into a place lels warm indeed, but which, however, has a fufficient degree of heat to make the ofillations, which become weatser and fainter, to ceafe at length entirely. That fuch is the caufe of the ceflation of the found may be proved by applying a frong heat to the part of the tube already heated, maintaining at the fame time the fame degree of heat under the bulb: by thefe means the limits of the temperatures are anin very abrupt, and the found will be reproduced in its fuli force. It may be readily conceived that the fubtance of the tube mut be fome matter a non-conductor of heat: glafs, therefore, is preferable.

Let us now compare the apparatus of a tube having a bulb with thofe tubes in which hydrogen gas is employed. In the latter we have every thing neceffary for the production of found, a vapour very hot, and conferuently highly elaftic; for, as already obferved, the place of the combuftion is at fo high a temperature that the beak of the glafs is confantly red. This bot and elaftic vapour, at the moment of its production, is in contact with the cold air, which enters the tube at the bottom and iffues at the top; its volume mutt then decreafe a moment after it has touched that cold air : new hot vapours fucceed the former, and contract in their turn. This alternate expanfion and contraction gives birth to the undulatory movement of the air, and fonorous undulations. 
We have already feen that an inflamed jet of fpirit of wirise or of ether cannot make the tube found. This is a new proof of what I have advanced, that to produce found there muft be a great difference between the temperature of the vapour and that of the furrounding air. In this cafe there is a fucceffive formation and condenfation of vapour, for the water ftreams along the fides of the tube; but the place of combution has a much inferior degree of heat to what it has when hydrogen gas is burnt, and confequently the vapour produced has lefs heat as well as lefs elafticity. This cafe is analogous to that already mentioned, when we faid that a fucceffive evaporation and condenfation of the liquid might be produced in a tube having a bulb, without any fonorous effects, by expofing the bulb to a certain degree of heat, but lefs intenfe than that neceffary for making the tube emit a found. We thould not be furprifed if lefs heat were produced by the combuttion of fpirit of wine, or ether, than by that of hydrogen gas, when it is confidered that in the latter cafe all the caloric contained in this gas, and in the oxygen of the atmofpheric air confumed, becomes fenfible heat, and unites itfelf entirely with the vapour produced. On the other hand, in the combuftion of an inflammable fubftance, fuch as fpirit of wine, we have only the caloric of the oxygen confumed, rendered fenfible, and which is in a great meafure abforbed by the formation of carbonic acid gas, fo that it is only the excefs which joins the vapour. It is therefore not aftonifhing that we have not heat fufficient to give to this vapour all the elafticity neceffary for the production of found: the prefence of the carbonic acid gas refulting from the combution may alfo be an obftacle to the fonorons vibrations.

In tubes employed with hydrogen gas, the found is much ftronger than in thofe having bulbs: befides, in the former it is permanent, in the latter it continues only a few moments. The reafon of this is as follows: In the apparatus with hydrogen gas the tube is open at both extremities, confequently there is formed a current of frefh air, which enters at the bottom and iffues at the top; this current of air fweeping along with the hot and elaftic vapours receives their impulfe, and, by taking from them a portion of caloric, diminifhes their volume: we find here, therefore, the moft effential condition for the production of an intenfe and permanent found, viz. a great difference between the temperature of the air and that of the vapour; and this difference always remains the fame by the continual renovation of the air; but this does not take place in tubes with bulbs, and therefore the found they emit is weaker and of horter duration.

From 
From this principle, that the great difference between the temperature of the vapour and air is neceffary for the production of found, it may be eafily conceived that every thing which tends to augment the heat of the current of air, and to diminifh that produced by the combuftion of the gas, will tend alfo to weaker or even to annibilate the found of the tube: but thefe two circumftances are united in a warm chamber filled with people: the current of air, inftead or being cool, is hot, and the quantity of oxygen being there lefs, the heat produced will be of lefs ftrength. It needs therefore excite no aftorifhment, that in fuch chambers the experiment does not always fucceed.

Brugnatelli produced founds in tubes merely by the combuftion of phofphorus. Some philofophers, conceiving that the fonorous effects were owing in a peculiat manner to the hydrogen gas, have been induced to infer the prefence of that fubftance in phofphorus. From what has been faid, is it not more fimple to explain this phænomenon by the production of the phofphorous acid under the form of vapours, which receive a great degree of elafticity from the caloric difengaged during the combultion, and the volume of which is foon diminifhed by the contact of the cold air? We find there the alternate expanfion and contraction neceffary for communicating to the air the undulatory motion proper for producing founds.

Such are the few obfervations I have had an opportunity of making on harmonious tubes; I hope they will prove in fome meafure interefting to thofe particularly engaged with this branch of philofophy, and that they will contribute towards making them pay attention to this curious fact hitherto neglected.

\section{On Painting. By Mr. E. DaYes, Painter. Essay V. \\ On Invention.}

Then, bold Invention, all thy powers diffufe,

Of all the fifters thou the nobleft mufe;

Thee ev'ty art, thee ev'ry grace infpires,

Thee Phocuus filds with all his brighteft fires.

MASON'S FRESNOY.

W

E thould never forget that the value of every art arife from the degree of mental capacity requifite to its production, and the degree of inftruction or pleafure refulting therefrom. 